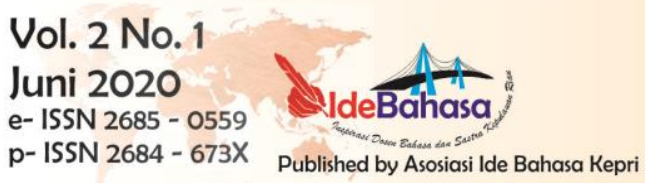

\title{
ESCAPING OF LACKNESS TROUGH FICTION FOR DESIRE AND EMPTINESS FULFILMENT
}

\author{
Tomi Arianto $^{1}$ \\ Putera Batam University, Batam, Indonesia \\ Email: tomi.arianto@puterabatam.ac.id \\ Ambalegin ${ }^{2}$ \\ Putera Batam University, Batam, Indonesia \\ Email:ambalegin@puterabatam.ac.id
}

\begin{abstract}
Popular fiction is a work that can not be released from the audience and special formulas so that it can be a place of escape from all human fatigue in all forms of activity. This research aimed to find the phenomenon of escaping lackness trough popular fiction. By using a popular fiction approach Cawelty (1976) and Adi (2011) combined with the concept of psychoanalysis, the researchers tried to explore the passion and emptiness in popular iron man 3 movie through characters, settings, and plots in the story. By using the audience analysis approach in descriptive qualitative method, there were several factors that form the formula in this action iron man 3 story to fill the audience's dreams and fill the emptiness in the audience so that the achievement of popularity can be achieved. The results of this study showed that Stark as the protagonist was described as a special genius who could develop knowledge and technology to respond to natural phenomena that had not yet occurred. The ability of producer to create images of the desires of technology power with the needs of the community made this film successfully debuted. Spiced up with the story of romanticism Stark and his lover add to the surprises that were generated in accordance with the desire that involves the audience immersed in the story.
\end{abstract}

Keywords: desire; emptiness; Iron Man 3; popular fiction; psychoanalysis

\section{Introduction}

Popular literature is a work of literature in great demand by many people. Its contents tend to be mild and follow the tastes of the people at that time. Unlike the noble literature whose creation is influenced by certain values, the popular literature is more concerned with market tastes. This is not surprising, because basically the creation of popular literature is only for entertaining, not to apply certain dogmas like noble literature. 
Popular literature consists of various forms, can be essays and some are fiction (Adi, 2011). Popular fiction can be interpreted as a fictional or imaginary work that is the result of the imagination of the author. Of course the imagination was not born without inspiration from the real life of the community, but then in the hands of the authors it was combined so that it gave birth to an interesting and not boring work.

At the beginning of its appearance, popular fiction was considered as a petty work, a lowly work because it contained only entertainment and did not contain the social values of society like noble literature. But in its development, this assumption began to disappear by itself; it is caused by the high acceptance of society against popular fiction. According to (Adi, 2011), it cannot be released with content contained in a popular fiction. It looks like the language is natural, easy to understand so that it can be enjoyed by any levels of society.

Public acceptance is higher when popular fiction becomes an industry and evolves which initially only took the form of text turned into films, soap operas, and drama. These changes make popular fiction easier to enjoy. Because basically people prefer things that have been visualized rather than having to read the text and then imagine it themselves.

The film "Iron Man 3" by director Shane Black is one form of popular fiction that is very accepted by the world community is no exception in Indonesia. It is could be proved by the amount of revenue in the first week of the screening of the film "Iron Man 3" which reached \$ 195.3 million obtained from 42 different countries (Azmil, 2013). According to the Disney studio that circulated the film, the biggest opening weeks were in Argentina, Hong Kong, Indonesia, Vietnam, Taiwan, the Philippines, Malaysia and Singapore (Huda, 2013). In Indonesia the number of viewers of the film "Iron Man 3" is more than the film "Fast and Furious 6", as revealed by coorporat cinema 21 that the film "Iron Man 3" is able to bring 3 million viewers while "Fast and Furios 6" brings 2 millions of viewers (hot.detik.com). The two projects showed how the audience is influenced by the concept of future technology depicted in the film "Iron Man 3".

The combination of advanced technology displayed in the film has also influenced many people, especially experts engaged in the IT field. This is proven by the development carried out by the American defense department in collaboration with Raytheon Sarcos. They developed clothes that are similar to those in the film. The suit allowed the soldiers who use it to lift weights of up to $70 \mathrm{~kg}$ without the slightest effort and can even break four layers of wood with just one blow (Sartika, 2013). In addition to clothing, the Lockheed Martin Company is also developing an outer frame project that can help soldiers lift weights of up to $400 \mathrm{~kg}$ with a maximum speed of 100 miles / hour in a long period of time (Unknown, 2013). The two projects showed how the audience is influenced by the concept of future technology depicted in the film "Iron Man 3".

From the facts above, it appears that this movie has brought its audience to the dreams of the future. They are helped to realize things that they cannot currently get in the real world. So that this film becomes a kind of impingement on what cannot be obtained in the real world. In Lacan's perspective, this happened because while watching the 
film he found a solution to meet what had so far been unfulfilled in him.

\section{Literature Review}

\subsection{Psychoanalysis and Popular Fiction}

The approach used in this is the Audience Analysis approach. This approach used to see how the cultural differences of connoisseurs of popular fiction give the same or different impression on it when it enjoys a popular fiction. The theory of psychoanalysis can be used to see the relationship between audience and popular fiction, because in discussing film we must look at the relationship between human psychological factors and the representation of a film. This theory is a systematic comparison between film as a spectacle and individual structure that is built socially and psychologically (Adi, 2011).

Psychoanalysis used in this paper is Jacque Lacan's psychoanalysis. Lacan's psychoanalytic theory considers the human subconscious always in a state of "lacking", so that there arises the desire to continue to cover up these shortcomings, rediscover what is lost, make humans return complete, perfect, and whole, find their identity, become himself again (Faruk, 2012).

In describing Lacan psychoanalysis has three concepts called mirror concepts:

1. The real, is methafore as when a new baby is born. Basically at the beginning of human life is only driven by needs so that it will be difficult for him to recognize as a part of other complete elements. In fact, it is difficult to distinguish between himself and the objects he faces. So that in this period, we don't see loss, lack and lack. In other words at this time a person is still in its original condition without influence from the outside world.

2. The Imaginary, is at the start of the mirror stage. That is when the baby begins to see his image in the mirror and recognize the image as himself. The image is no longer fragmented as before; the shadow is believed to be me.

3. The Symbolic is when the hidden desires begin to be owned by the child. This desire can arise at any time in the form of behavior and language.

\subsection{Popular Fiction}

The term popular fiction is derived from the term mass culture contained in the categorization of culture into elite / high culture (high) and mass culture (low). Neuburg, (1977), in the book popular literature a history and guide, based on the development of popular literature in England in the 19th century, defines popular fiction is what the unsophisticated reader has choosen for pleasure. Thus, according to him popular fiction is the reading of readers from ordinary circles for entertainment.

Among a few theories about formulas in popular fiction, the theory of John G. Cawelti turned out to be the most widely read and used as a reference in discussing popular fiction of the century. In his book titled Adventure, Mystery, and Romance Cawelty (1976) stated that the understanding of formulas in popular literature is the same as the term genre in the discussion of high-level literature or classical literature. Cawelty (1976) said that the formula is the combination or synthesis of several specific cultural conventions 
with a more universal story form or archetype.

If in the discussion of classical literature, it knows the division of genres such as fiction, drama, and poetry, then in popular literature there is adventure, action, mystery, romance, alien being and state, and melodrama or tragedy. Judging from this understanding, action is one part of the overall popular literature. By using the popular fiction approach, the disclosure of formulas and archetypes can be explored further.

\subsection{Synopsis of "Iron Man 3" movie}

The film "Iron Man 3" began with Tony Strak's meeting with a scientist named Aldirch Killian who invited him to work together at a company called Advance Idea Mechanic (AIM), then Stark promised to follow him 5 minutes later. However, it turned out that Stark forgot his promise because he was tempted by a beautiful scientist named Maya Hansen, and they spent the night together. Due to the incident, Killian was disappointed and held a grudge against Stark.

One time after the events of The Avengers, Tony Stark made some Iron Man clothes at his house. His hobby led to a dispute with his girlfriend, the new Stark Industries chairman Pepper Potts. In the United States today, a series of bombings carried out by Chinese terrorists confuses intelligence agents because there is no forensic evidence. After Stark Industries security chief Happy Hogan fell victim to one of his attacks, Stark rose and threatened Mandarin on television. Mandarin responded by destroying Stark's house using armed helicopters. Potts and Hansen, who came to warn Stark, survived the attack. Likewise, Stark realized that he was in rural Tennessee after the JARVIS artificial intelligence program carried out the flight plan he had compiled earlier to track Mandarin. Stark's battle suit force is not enough to return to California, so the world believes Stark was killed.

Along with Harley, a curious 10-yearold boy, Stark investigated remnants of explosions in the city that are similar to the Mandarin attacks on Los Angeles. He discovered that the explosion was carried out by soldiers from the Extremis program, a trial that allowed its users to recover from severe injuries. However, if the user's metabolism is unable to absorb Extremis, his body will heat up and explode. After the veterans began to become unstable and explode, their deaths were used to cover Extremis's failure by compiling terrorist plots. Stark first saw Extremis when Mandarin agents, Ellen Brandt and Eric Savin, attacked him.

With the help of Harley, Stark traced Mandarin to Miami. Stark infiltrated the headquarters using various homemade weapons. There he learned that Mandarin was actually a British actor named Trevor Slattery who was not aware of Mandarin actions. Mandarin is actually the imagination of Killian. Killian used Hansen's Extremis research as a remedy for his limitations and developed the program so that it could be used by wounded war veterans. Killian reveals that he has kidnapped Potts and put him into the Extremis program with the aim of giving Potts super abilities and fighting Stark so that Killian gets Stark's help to fix Extremis's flaws.

Killian has also manipulated US intelligence agents about the location of Mandarin by trapping James Rhodes, a former War Machine user, now changing 
his name to Iron Patriot so that his armor can be stolen. Stark escaped from his custody and meets Rhodes. They learned that Killian would attack President Ellis on Air Force One. By controlling Iron Man remotely, Stark managed to save the passengers and crew but failed to stop Killian. They tracked Killian to the oil drilling rig. There Killian would kill Ellis directly in front of the camera. The Vice President would be made a puppet leader who obeys Killian's orders in return for healing his daughter's disability by the Extremis program.

On the bridge, Stark rescued Potts, while Rhodes saved the President. Stark mobilized all his Iron Man clothes remotely controlled by Jarvis as reinforcements. Rhodes secures the President, while Stark discovers that Potts survived the Extremis procedure. However, before Potts could be saved, the bridge collapsed and he fell from a height of 60 meters. Stark was forced to fight Killian trapping him in an Iron Man suit that could explode on its own. Killian survived the explosion of the shirt, but was killed by Potts who was saved by his Extremis power.

After the battle ended, Stark ordered JARVIS to destroy all of Iron Man's clothes as a sign that he wanted to spend more time with Potts. Both the Vice President and Cassidy were arrested. Potts underwent surgery to remove the effects of Extremis and Stark underwent removal of broken iron near his heart. He then throwed his heart reactor into the sea, but still considers himself an Iron Man without a battle suit.

\subsection{Previous Study}

Journals that discussed the study of popular in fiction are still rarely done. This approach can be said to be still new, looks simple, but produces analysis that is often beyond the study in general. Behind all that, there were some studies that were contributive enough to be a state of art in this study.

Scopus indexed research written by Ohmann (2019) could be used as reference. Ohman discussed how to read in a new dimension using a popular fiction approach to Harlequin's novels and other popular books. He discussed how reading the romance: women, patriarchy, and popular literature. In contrast to what is done by researchers from this journal, researchers focus on the relationship between formulas and the archetype of action films related to the expectation horizon owned by the audience as a form of fulfilling desires and emptiness. Along with it, Mcrobbie (2004) also provided an insight into the relationship between feminism and popular literature. Through the reading of Giddens and Beck, Mcrobbie understood post-feminism to refer to an active process by which feminist gains from the 1970s and 80s come to be undermined.

The article of Keshner (1989) which made references to the application of Bakhtin theoretical concepts in popular works to uncover the facts of joyement, apparent awareness, and popular literature can also be used as references in the development of popular fiction themed article ideas. Keshner believed that the joyce attitude towards popular literature was not as simply scornful as dismissive as the migh imply episode. Along with the same publication, Fahs (2001) contributed to develop an idea about the analysis of fiction that were popular during civil war in America. Stories like Harper. Godey, Frank Lesley, Nixnext, Budget of fun, etc. in addition to 
presenting a slick story and everyone's interest also gave a spirit of patriotism for the citizens of short America to continue to fight during the civil war.

Contemporary analysis written in the article Linda (2018) which raised the formulas and archetypes in popular literature in Walt Disney movie animation can also be used as a reference. There is a production that actually makes no sense in Disney stories but on the other hand it makes no sense the story makes it interesting so that it can be accepted by the audience. Arianto (2019) also contributed in analyzing two Japanese heroic stories Miyamoto Musashi and Rurouni kenshin using an approach Cawelty (1976) related formulas and archetypes in the action story. The results of the study indicated that the two action legends generally have the same action story formula as the cawelty formula, story / narrative structure, and similar motives for action. Arianto (2018) also analyzed an ideological formula of romanticism in Whitman's Walt poems. Romanticism in the sense not as stories of romance and romance, but an understanding of great ideas about maintaining the freedom of individuals, sovereignty, and independent of human rights.

\section{Research Method}

This research is used the method of desriptif qualitative trough Audience Analysis technique. This approach used to see how the cultural differences of connoisseurs of popular fiction give the same or different impression on it when it enjoys a popular fiction. The method that was used in this research was library research and close reading. Qualitative research is best suited for fictions phenomena because literature is a world of words and symbols that are full of meaning. Literature is not a phenomenon that easily calculated like the phenomenon of natural science (Ratna, 2004). An important feature of qualitative research in literary studies according to Endraswara (2011) are: 1) researchers are a key instrument will read carefully the fiction, 2) research done on a regular basis descriptive, meaning decomposes in the form of words or images if necessary, not a number, 3) preferring process rather than result, because fiction is a phenomenon that invites many interpretations, 4) inductive analysis, 5) meaning is the mainstay. This research was done through two stages, namely data collection and data analysis. However, before the two stages of the research were described, it was necessary known place of research, population, sample, and data in this research.

\section{Result and Discussion}

As explained above, basically the human subconscious is always in a state of inadequacy, so it requires others to fulfill it. This fact is related to the results of research conducted by Radway in (Adi, 2011) that women who read popular novels are a reflection of the needs, desires and haroas or dreams they do not get from their husbands or partners even though they have a happy family. From this fact, it can be concluded that it is not only women who need an escape to seek an end, but also applies to humans in general. And not only for novels, it is could be found in the form of a film.

What is felt by women also applies to humans in general. They watch movies to find fullness and satisfaction. 
This can be seen from the author's observations in several online media that include how they think of the film "Iron Man 3", it can be concluded that in the film there is an answer to the search conducted by people in general.

In "Iron Man 3" movie described that Tony Sark is a genius and has a fairly large company. Not surprisingly with the wealth he has he is able to buy everything he wants. Luxury cars, sophisticated gadgets and even houses complete with facilities that are certainly very luxurious. And don't forget, beautiful women always accompany him.

From the scene it is very clear that the film "Iron Man 3" presents things that not all of them can be realized in the real world. Thus the audience will compare what happens in the film with the conditions they experience. Therefore, the film is interesting for him because it can show what is not in his real life. So that the scene continues to haunt him and give the dream desire to the audience. According to Lacan it is human nature to look for what is not yet present in him.

Thus, between popular fiction and dreams provide indirect satisfaction aimed at the desires of the reader when reading or watching a popular fiction (Adi, 2011). So, every time someone watches popular fiction in which there are dreams that unconsciously want to be fulfilled, then he likes to watch movies even though for a long time.

While watching 'Iron Man 3, the features a scene of Stark has been a sophisticated armor. The robe is controlled by a soft set called JARVIS. JARVIS can do whatever commands are instructed by Stark. So he does not need to bother to know the events that occur outside his home. JARVIS is also used by
Stark to track terror carried out by Mandarin, he only instructs the robot to display the holographic plan of the scene, and finally can find out how the exact conditions of the event along with JARVIS analysis. Even JARVIS can also be a friend to share without worrying about being leaked to others

In the real world, every person would want to have these devices, with people no longer need to bother. If you want something, it could be order the robot to do it. So, it will be more effective in doing the work. However, again this has become a desire of humans.

In the film also known as the term Psychology of Empthy, it is emphasized so that the audiences when seeing the image feel emotionally and intrigued. By playing the emotions of the audience, their desires and subconsciousness will feel different sensations when they see the different scenes displayed in the film.

Some scenes that make the audience's emotions melt in it, namely when Stark had an affair with another woman, even though he already has a lover who is also the leader of Stark Indutries named Papper Pott. This sparked a dispute between the two, Papper then left Stark. It is affected the disapproval of several projects proposed by Stark. At the same time, Strak also felt frustrated at not being able to express himself as before. To reduce his emotions Stark refocused to develop his armor. With the help of his homemade serum, he can survive not sleeping for 72 hours. So that finally his body felt weak, seeing this condition Papper returned to the arms of Strak and helped him recover.

The film has another effect on how we see dreams. Psychologically, the film 
can give viewers an idea to see things from a different perspective. Psychological approach emphasizes how the concept of one's consciousness in forming a scheme about self or theoretical ideas. It can be reflected from how a pessimistic audience can be optimistic after watching a film. The ability of film directors to play the scene gives a surprise to the audience. It is the desire for satisfaction with surprise that then awakens the emotions of the audience. Thus, the emotional ups and downs of the game bring different psychological responses. One of them when passing through conflict from adversity into a victory. This indirectly triggers the psychological change from pessimistic to optimism after watching the story.

Stark whose house was attacked by terrorists and then through the Javis system can escape. However, when he realized he did not know where he was. With the condition of the body full of blood and navigation system Javis that has been damaged resulting in it must settle in a place that had never been visited. He felt despair so he just kept quiet and did nothing. Until finally he met a child named Harley and found new hope. Stark began to improve Javis's navigation system, until finally everything returned to normal. And Stark can find the terrorist who destroyed his house.

On the other hand, Papper's determination in serving Stark also produced something extraordinary. Initially he was just an assistant who took care of all the needs of Stark. Stark often behaved unworthily of him, but eventually he became chairman of a large Stark Industries company. Not only that then Stark made him a lover and promised not to cheat him.

The similarity of human desires is also one of the reasons for the emergence of popular fiction that touches the reader's feelings, because popular fiction provides a way out of the desires that are found in humans (Adi, 2011). With the touch of a work on the audience, it can be a way out for hidden desires. So the film can become one of the ways for people who want to express their desires.

This is inseparable from the general nature of human beings who have the desire or dream to be able to live decent lives, swaying wealth, all work feels easy and of course to have a life partner. This is evidenced by the high public interest in watching the film "Iron Man 3". The audience is generally interested in the story line and social status shown in the film. Another factor that makes this film so popular is because this film displays the technological sophistication of the future. All the scenes are accompanied by future technology shows which do not exist in real life, so that it fosters the desires and dreams of the audience.

\section{Conclusion}

The film "Iron Man 3" was interesting because the scenes can fulfill human desires in general. By using a popular fiction approach developed by Cawelty (1976) and Adi (2011), researchers revealed a formula and srketype in the film Iron Man 3. The life of a man who is swarming with all the luxurious amenities, along with the technological sophistication displayed in this film makes "Iron Man 3" quite worth mentioning as a film that can fulfill the desires and emptiness of the audience. The story of the heroic action in the film 
Iron Man was produced in such a way with the aim of none other than to get the maximum benefit even though many elements of hypperreality were presented but as if heeded. Another thing was precisely this work was so accepted by the public to meet a lack of achievement over the lack of viewers and fill these gaps. Proven in this film was one of the epic stories born throughout the centuries and continues in subsequent sequels with other surprises of course by Marvel movie production.

\section{References}

Adi Rochani, I. (2011). Fiksi populer: Teori dan metode kajian. Pustaka Pelajar.

Arianto, T. (2018). National romanticism in Walt Whitman poems. Lire Journal, 2(1), 14-20. https://doi.org/https://doi.org/10. 33019/lire.v2i1.18

Arianto, T. (2019). The analysis of formula in the legend of Japanese samurai Rurouni Kenshin and Miyamoto Mushasi: Popular literary approach. Jurnal BASIS, 6(1), 55-64. https://doi.org/https://doi.org/10. 33884/basisupb.v6i1.1047

Azmil, F. (2013, July). Kecanggihan teknologi Iron Man bukanlah mimpi. Merdeka.Com, 24. https://www.merdeka.com/teknol ogi/kecanggihan-teknologi-ironman-bukanlah-mimpitekmatis.html

Cawelty, J. G. (1976). Adventure, mystery, and romance. University of Chicago Press.

Endraswara, S. (2011). Metodologi penelitian sastra. Pustaka Pelajar.

Fahs, A. (2001). Popular literary culture in wartime. The Univeristy of North Carolina Press.

Faruk. (2012). Metode penelitian sastra: Sebuah penjelajahan awal. Pustaka Pelajar.

Huda, M. K. (2013). Iron Man 3, terobsesi dan sangat mengobsesi. Mkhuda.Com. https://mkhuda.com/teknologi/iro n-man-3-terobsesi-dan-sangatmengobsesi/

Keshner, R. B. (1989). Joyce, Bakhtin, and popular literature. The Univeristy of North Carolina Press.

Linda, L., \& Arianto, T. (2018). Child literature genre formulation in Walt Disney animation movie. Jurnal Basis, 5(2), 11. https://doi.org/https://doi.org/10. 33884/basisupb.v5i2.776

Mcrobbie, A. (2004). Post-feminism and popular culture. Feminist Media Studies, 4(1), 255-264. https://doi.org/https://doi.org/10. 1080/1468077042000309937

Neuburg, V. (1977). Popular literature: A history and guide. Routledge.

Ohmann, R.M. (2019). Reading the romance: Women, patriarchy, and popular literature. Radical Teacher, 113(3), 23-24. https://doi.org/https://doi.org/10. 5195/rt.2019.575

Ratna, N. K. (2004). Teori, metode, dan teknik penulisan sastra. Pustaka Pelajar.

Sartika, K. (2013, April). Di berbagai negara, penonton Iron Man 3 melebihi The Avengers. Tabloid Bintang. https://archive.tabloidbintang.com /film-tv-musik/kabar/66848-diberbagai-negara,-penonton-ironman-3-melebihi-the-avengers.html Unknown. (2013). 10 hal yang tidak anda 
Vol. 2 No. 1

Juni 2020

e- ISSN 2685 - 0559

p- ISSN 2684 - 673X

ketahui tentang Iron Man. Blog Eutika.

https://eotika.blogspot.com/2013/

06/10-hal-yang-tidak-anda-

ketahui-tentang.html 